\title{
MSME-Based Industrial Development Strategy Through the Role of LPDB (Revolving Fund Management Institution) and South Sumatra UMKM Readiness Facing the Digital 4.0
}

\author{
Tien Yustini \\ Management Program, STIM AMKOP Palembang, Indonesia \\ E-mail: yustini28470@yahoo.com
}

$\begin{array}{lc}\text { Received: October 1, } 2018 & \text { Accepted: October 19, } 2018 \quad \text { Published: November 21, } 2018 \\ \text { doi:10.5296/ber.v8i4.13725 } & \text { URL: https://doi.org/10.5296/ber.v8i4.13725 }\end{array}$

\begin{abstract}
This study aims to analyze various issues related to the distribution of revolving funds for Small and Medium Enterprises and Cooperatives in South Sumatra. The analysis was carried out by describing the absorption of revolving funds in MSMEs and the potential absorption of labor in the MSME sector quantitatively. The results of the analysis show that MSMEs in South Sumatra generally face some fundamental problems, pillars are self-sufficient. First, the problem of capital, both marketing, "For capital issues may still be overcome. Because the government through the banking and the Ministry of Cooperatives can provide sufficient access to provide loan capital. However, on the marketing side is still very lack of knowledge." Marketing is a problem. To overcome these problems, SMEs in South Sumatra were addressed, by improving product quality and standardizing their products. Besides helping increase human resources and access to financing sources, collaboration between government and e-commerce will continue and be able to realize a shared vision to make MSMEs in South Sumatra able to participate in the era of Digital Energy of Asia in 2020. In an effort to encourage this growth, the provincial government of South Sumatra has facilitated new business actors and existing SMEs to expand their business by holding socialization and training in various district / city areas. Business actors can also get training, which cooperates with the Cooperative Education and Training Agency (UPTD Balatkop) in regencies / cities in South Sumatra. The trainings are funded with deconcentration funds. The Ministry of Cooperatives and SMEs will support and will provide training, capital by providing cooperative loan facilities for SMEs through the Revolving Fund Management Agency (LPDB). Through LPDB, facilitated SMEs for cooperatives can be capital loans with
\end{abstract}


7 percent interest. For business actors already legal entities can borrow 4.5 percent

Keywords: Digital energy, Revolving fund, E-commerce

\section{Introduction}

Various political activities have a positive impact on the economy, the political year will also not make entrepreneurs take a wait and see step. This is because in the moment of a democratic party there will be a lot of non-household consumption. There are expenditures made by non-household institutions that can encourage private consumption. This will contribute positively to pre-economics in 2018 - 2019, optimistic that the political atmosphere surrounding Indonesia this year will not have a negative impact. "Regarding political perception, we believe we are mature enough and we can maintain stability (Firman Mochtar, 2018).

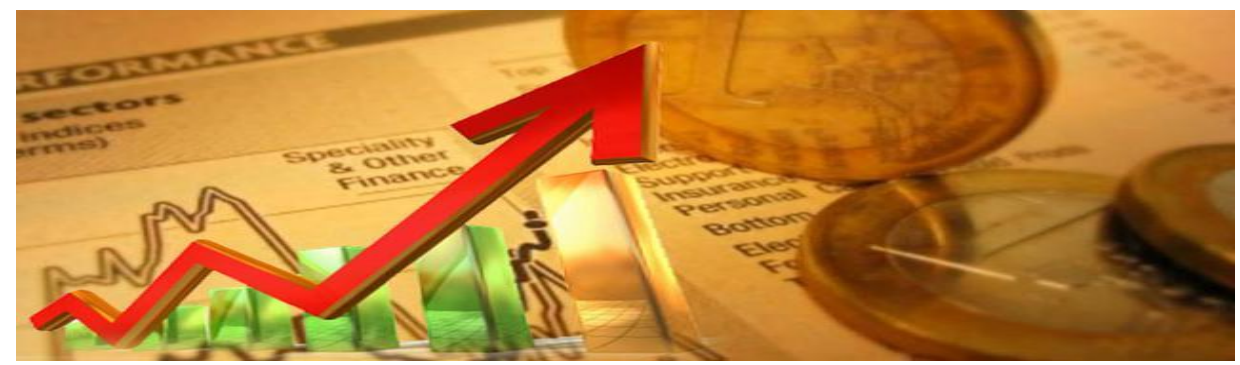

Figure 1. Illustration of World Economic Growth (Liputan6.com/Andri Wiranuari, 2018)

According to Deputy of Indonesian Bank (2014) that estimates the Indonesian economy will grow better in the first quarter of this year compared to the same period last year. This is supported by domestic demand, especially investment, so that the projections of the national economy can grow in the range of 5.1-5.5 percent in 2018. Investment shows an increase, both in building and non-building investment. "Building investment is increasing in line with the progress of infrastructure projects by the government and the private sector. Meanwhile, the increase in non-building investment mainly occurs in the primary sector, especially mining. Economic growth in the first quarter of 2018 is expected to be lower than the fourth quarter of 2017. In the final quarter of 2017 economic growth was recorded at 5.19 percent. "First quarter growth was slightly lower than in the fourth quarter of 2017. However, economic growth is expected to improve in the second quarter and third quarter 2018. While on an annual basis, economic growth in 2018 is believed to be higher than 2017 "For the whole year there will be an increase in the second quarter and third quarter. We see that for 2018 it will be above 2017.

Based on estimates from Bank Indonesia (BI) the figure of DKI Jakarta Gross Regional Domestic Product (GRDP) in 2016 grew by $5.85 \%$ on an annual basis. Previously, the Minister of National Development Planning/Head of Bappenas, Bambang Brodjonegoro said Indonesia's economic growth was difficult to penetrate more than 5.5 percent if only relying on natural resource exports. Therefore, a breakthrough from the industrial sector must continue to be improved so that it can pass through Indonesia's economic growth rate. Furthermore, BI Governor Agus Martowardojo said that economic growth in the first quarter 
would still not be far from the 5.1 percent figure. But this is still in line with BI's expectations. Throughout 2018, economic growth will be in the range of 5.1 to 5.5 percent. "If from BI, economic growth is 5.1 to 5.5 percent. Maybe in the first quarter, there was 5.11 percent, (2018).

The government targets the national industrial sector to grow in the range of 5.1 to 5.6 percent. To achieve these targets, the government will focus on improving and implementing several strategic issues. "Some of these strategic issues such as encouraging increased value-added manufacturing, boosting the business climate, encouraging increased productivity, technological content, and increasing exports of manufactured products," Specifically for the increase in added value, the government will focus on five industrial developments. Among them are the development of agriculture-based MSME industries, the development of upstream industries, supporting industries, and industrial zones, increasing manufacturing exports, developing industrial human resources competencies through vocational education, and increasing industrial research and development.

The Bank Indonesia Business Activity Survey in the first quarter of 2018 shows an increase in business activities. Followed by the improved performance of non-financial corporations in various sectors. Likewise, private consumption is expected to increase, supported by strengthening purchasing power, along with improvements in income and accelerated distribution of social assistance, as well as increased expenditures related to simultaneous local elections.

Regarding Small and Medium Enterprises and Cooperatives, the Ministry of Cooperatives and Small and Medium Enterprises (Kemenkop UKM, 2008) launched as many as 3.79 million micro, small and medium enterprises (MSMEs) already utilizing online platforms in marketing their products. This number is around 8 percent of the total MSME players in Indonesia, which is 59.2 million. To grow the number of MSME players who surf in cyberspace, the Ministry of Cooperatives and Small and Medium Enterprises and the Ministry of Communication and Information together with e-commerce actors initiated the program that is titled 8 Million UMKM Go Online. Through this collaboration, the government also hopes to accelerate the transformation of MSMEs in Indonesia towards digital. "The UMKM players must be the main players in the development of digital economy in Indonesia. We have a target on how to make 8 million MSMEs go online in 2019 according to Minister of Communication and Information Rudiantara, in the Harmoni area. In Indonesia, such as Lazada, Shopee, MatahariMall.com, BliBli.com, Bukalapak, Tokopedia, and Blanja.com, those who attended the event also briefly expressed their commitment to joining this program. They said they would run a roadshow to educate the public so that the entrepreneurial spirit would be built

Each e-commerce has its own program. For example, pedestrians in Bukalapak have land coffee programs in their respective regions to empower their communities. In addition, Blanja.com made several synergies with the Ministry of BUMN to hold roadshows in several regions to Eastern Indonesia. Kemenkop said, in addition to empowering SMEs, this movement would help provide financial access to entrepreneurs. Kemenkop will help ensure 
that products produced by UMKM are competitively competent and that their capacity is sufficient so as to gain trust from funding sources.

It is expected that the new SME entrepreneurs will grow by around 5 percent in 2019. This is considering the growth of Indonesia's population each year "Target 20184 percent, End 2019, targeted reached 5 percent. In the three years of the Jokowi-JK Government, the number of SME entrepreneurs in Indonesia rose from 1.56 percent in 2014 to 3.1 percent of the total population at the end of 2016. Therefore, the government is optimistic that by 2019 it can reach the 5 percent target of the population.

The problem is that MSMEs face several fundamental problems, the pillars are self-sufficient. First, the problem of capital, both marketing, "For capital issues may still be overcome. Because the government through the banking and the Ministry of Cooperatives can provide sufficient access to provide loan capital. However, on the marketing side is still very lack of knowledge." Marketing is a problem. In the marketing problem we have several obstacles. Based on that problem, this study aims to analyze the Analysis of MSME-based Industrial Development Strategies and South Sumatra UMKM Readiness to face the era of Digital Disruption 4.0.

\section{Theoritical View}

Micro, Small and Medium Enterprises (MSMEs) are defined as microbusinesses which are productive businesses owned by individuals and / or individual business entities that meet the criteria of Micro Enterprises. UMKM is also defined as a small business with a stand-alone productive economic business carried out by an individual or business entity that is not a subsidiary or not a branch of a company that is owned, controlled, or is a direct or indirect part of the Medium Business or Large Business who meets the criteria of Small Business as referred to in Act Number 20 of 2008 concerning Micro, Small and Medium Enterprises

According to Law Number 20 of 2008 concerning Micro, Small and Medium Enterprises, MSMEs are defined as follows: "Medium Business is a productive economic enterprise that is independent, carried out by an individual or business entity that is not a subsidiary or branch of the company owned, controlled, or become part of directly or indirectly with Small Business or Large Business with the amount of net assets or annual sales results as stipulated in this Law." While Bank Indonesia defines MSMEs based on the number of workers, including (1) El Salvador (less than four people for micro-enterprises, between five and 49 people for small businesses, and between 50 and 99 people for medium-sized businesses); (2) 2. Ecuador (less than 10 people for micro businesses); (3) Colombia (less than 10 people for micro businesses, between 10-50 people for small businesses, and between 51 - 200 people for medium businesses); (4) Morocco (less than 200 people); (5) Brazil (less than 100 people); (6) Algeria (non-formal institutions have fewer than 10 employees).

Some countries have different standards and some use a combination of various benchmarks in defining MSMEs related to the legal basis. South Africa, for example, uses a combination of number of employees, business income, and total assets as a measure of business categorization. Peru based MSME classification based on the number of employees and the 
level of sales per year. Costa Rica uses a point system based on labor, annual sales, and total assets as a basis for business classification. Bolivia defines MSMEs based on labor, sales per year, and the amount of assets. While the Dominican Republic uses employees and annual sales rates as a benchmark. The Taxis have different classifications under different rules, but there is a general consensus that defines MSMEs based on the number of employees.

Micro enterprises are also a market segment that is potential enough to be served in an effort to improve its intermediation function because micro-businesses have positive and unique characteristics that are not always owned by non-micro businesses, including: (1) Turnover is quite high, its ability to absorb expensive funds and in the economic crisis situation business activities are still running and even growing; (2) Not sensitive to interest rates; (3) Keep developing despite the economic and monetary crisis situation; (4) In general, the character is honest, tenacious, innocent and can receive guidance as long as it is done with the right approach.

Business development is a form of business to the business itself in order to develop better and to reach a single point or peak to success. Business development is carried out by businesses that have begun to process and there is a possibility to progress further. According to Purdi E. Chandra, business development is a condition where there is an increase in sales turnover. The development of business including business development of MSMEs can be divided into 4 stages, namely conceptual stage, start up, stabilization, growth stage, and maturity. This study will discuss business development seen from the conceptual stage, namely (1) know potential opportunities in which in knowing the potential opportunities that are important to know is the problems that exist in the market, then find solutions to problems that have been detected. This solution will be an idea that can be realized; (2) Analysis of opportunities in which actions that can be taken to respond to business opportunities are by analyzing opportunities in the form of market research to potential customers and this analysis is carried out to see customer responses to their products, processes, and services; (3) Organizing resources in which it takes to know what needs to be done when a business is established is to manage human resources and money. At this stage, what is often referred to as the stage of starting a business and at this stage it is said to be very important because it is the key to success at the next stage; (4) Resource mobilization steps.

The step of mobilizing resources and accepting risk is the last step before going to the start up stage. The development of Micro, Small and Medium Enterprises is essentially a joint responsibility between the government and society. Micro, Small and Medium Enterprises initially did not experience very significant progress both in terms of quantity and quality due to lack of serious attention from the authorities. Since the monetary crisis in 1997/1998 where MSMEs turned out to have relatively good resilience compared to large businesses, the attention was immediately directed towards the development of UMKs both in terms of quality and quantity and began to show significant improvements to the country's economy in the post-reform era. The development of MSMEs is inseparable from the support from the central and regional governments, especially from the regulations issue. 


\section{Methodology}

The method used in this study is a case study method that aims to find out more about the characteristics, and characteristics of each individual, group, and community in an area. In addition, the researchers also provided an overview of the profile of MSME business recipients of revolving funds from LPDB submitted through the Department of Cooperatives and MSMEs of South Sumatra Province. The group of revolving fund users obtains revolving loan funds in the last two years namely 2016 and 2017 which have productive businesses. The sampling technique uses nonprobability sampling and analysis is carried out by the descriptive method which is carried out using two forms of approaches, namely quantitative approaches and qualitative approaches. Meanwhile, the type of data used includes primary data (interviews with citizens) and secondary data (reports on the Division of Financing at the Department of Cooperatives and SMEs of South Sumatra Province).

\section{Discussion}

Micro, Small and Medium Enterprises is one sector that plays a role in reducing inequality and poverty in Indonesia because it can provide employment opportunities that are broader than the formal sector. The development of Micro, Small and Medium Enterprises is increasing in terms of quantity (business units) and the potential they have not been offset by the prevalence of quality improvement. One of the problems found in Micro, Small and Medium Enterprises is the low ability of these business actors. The business capability is influenced by several factors that can be grouped into two groups, namely individual characteristics and characteristics outside the individual. Individual characteristics include business capital, creativity and innovation, social capital, and gender differences. Meanwhile, the characteristics outside the individual are cooperation between stakeholders.

Micro, Small and Medium Enterprises (MSMEs) play an important role in the structure of the Indonesian economy. Based on Bank Indonesia's data, in 2016 the MSME sector dominated 99.9 percent of business units in Indonesia and was able to absorb almost 97 percent of the Indonesian workforce. From this figure, the type of micro business absorbs the workforce up to 87 percent. While large businesses can only absorb 3.3 percent. The emergence of MSME players is expected to be able to be a driver of domestic economic growth. However, to encourage the development of the MSME sector is not easy, there are many things that need to be improved, one of them is the marketing method. Amid the current advances in digital technology, the MSME sector must take advantage of the emergence of the phenomenon of digital economy or e-commerce. Contributions for Manpower Absorption in Indonesia in 2016 appear in the following figure (Source:

https://databoks.katadata.co.id/datapublish/2016/11/23/umkm-serap-97-perja-indonesia): 
Kontribusi Penyerapan Tenaga Kerja

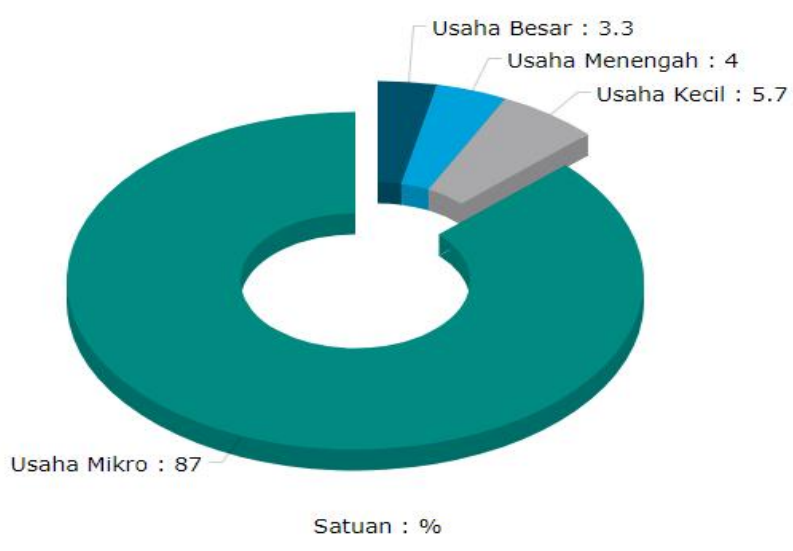

() (1) $\odot$

\begin{tabular}{ll|l|l|}
\hline TAGS & UMKM & Pekerja & Tenaga Kerja \\
\hline
\end{tabular}

Figure 2. Manpower Absorption in Indonesia 2016

The development of MSMEs that has increased in terms of quantity (business units) has not been matched by the prevalence of improved quality of MSMEs. Problems that are often faced are low productivity. This condition is caused by internal problems faced by MSMEs: low quality of human resources (HR) of MSMEs in management, organization, mastery of technology, and marketing, weak entrepreneurship of MSME players, and limited access to MSMEs to capital, information, technology and markets and other production factors. While the external problems faced by MSMEs include the amount of transaction costs due to the unfavorable business climate and the scarcity of raw materials. Also concerning the acquisition of formal legality which until now is still a fundamental problem for MSMEs in Indonesia, following the high costs that must be incurred in obtaining permits. Meanwhile, a lack of understanding of cooperatives as business entities that have an institutional structure (organizational structure, power structure, and incentive structure) that are unique / typical compared to other business entities, and lack of information about correct cooperative practices (best practices) causing low quality of cooperative institutions and organizations. Along with these problems, cooperatives and MSMEs also face challenges, especially those caused by the rapid development of economic globalization and trade liberalization along with the rapid rate of technological progress.

From 2008 to 2017, the Revolving Fund Management Agency (LPDB) KUMKM has distributed as much as Rp. 21,650,000,000 in the province of South Sumatra. In 2017, the LPDB allocated a revolving fund budget of Rp. 40.35 billion for KUMKM in South Sumatra Province. Given the large potential of the productive sector, the realization of the absorption of revolving funds is very unfortunate. For this reason, LPDB again socialized the revolving fund distribution program, as well as providing technical guidance on how to access LPDB revolving funds to KUMKM in South Sumatra. To explore the productive sectors in the Province, so far almost $70 \%$ of financing has been channeled to savings and loans. Therefore, this productive sector has considerable added value, so that it will become LPDB 
concentration.

So far, South Sumatra's absorption of LPDB funds is still relatively small, so it is expected that having productive sectors such as coffee, patchouli, rubber, palm oil and so on can also get a large allocation of funds. As for the interest rate that applies in LPDB, it covers $4.5 \%$ nawacita program (agriculture, fisheries, plantations), 5\% real sector (KUMKM manufacturing, handicraft, creative industries), 7\% savings and loans (savings and loan cooperatives, LKB, LKBB and BLUD), and for sharia financing, namely profit sharing 40:60 (KSPPS / USPPS, LKB Syariah, LKBB Syariah). So that cooperatives and SMEs in Sumatra can take advantage of LPDB revolving fund financing, especially the financing of working / business capital with sharia patterns that have been presented by LPDB.

The South Sumatra Provincial Government assesses that uptake of revolving funds from the central government to small and medium-sized businesses and cooperatives has not been maximized. This can be seen from the low realization of funds channeled by the Revolving Fund Management Institute (LPDB) in the province. Even though the interest rate pegged by LPDB is quite low, around $7 \%$ is smaller if compared to the interest rate applied by banks nationally, the revolving fund that has not been absorbed is quite a lot, worth IDR 4 trillion. Therefore, the local government also sought to increase LPDB fund absorption. One of them delivered the program to business people in South Sumatra.

One of the causes of the non-optimal revolving fund program is the low ability of debtor candidates to pay, which makes the debtor reluctant to use the facilities of the government. Ahmad said debtor candidates also often do not meet the requirements to be able to use revolving funds, as there must be a financial report, there must be an annual member meeting and other administrative equipment.

All the conditions that are determined are aimed at seeing whether the prospective debtor's business is healthy or not because it will be related to the ability to repay funds," he said. Data from the regional government shows that the number of KUMKM that have received such assistance has continued to decline over the past few years. In 2016, there were 11 recipients of funds with a total value of IDR 20.24 billion while in the previous year there were 13 KUMKM partners who used the funds with a realization of IDR 46.07 billion. Furthermore, the funds will only be absorbed by 10 UMKM partners totaling Rp24 billion in 2017.

Meanwhile, it was quoted from the official website of LPDB, the financing institution has distributed funds of up to Rp. 515.68 billion on May 6, 2015. It is estimated that by the end of 2017, the amount disbursed will exceed the distribution in 2016 which reached Rp 1.153 trillion, "distribution target of Rp 2.35 trillion with 940 partners to 174,072 MSMEs this year." Of that amount, $60 \%$ or Rp. 1.42 trillion will be channeled to cooperatives (savings and loans and non-SP real sectors) to 564 partners and involve 104,444 MSMEs Managing Institutions of Revolving Funds for Cooperatives and Micro and Small and Medium Enterprises (LPDB-KUMKM ) channel revolving funds with a new paradigm. This new paradigm involves guarantee companies, namely Jamkrindo and Jamkrida, as the first party analyzes the feasibility of the proposal. (Adi Trisnojuwono, 2017). 
Since 2008 LPDB-KUMKM through the Department of Cooperatives and MSMEs in the Sumatra Province of Seatan has distributed funds of Rp.211.2 billion or around $2.4 \%$ of the total distribution of LPDB-KUMKM. The government has allocated a revolving fund budget for South Sumatra around Rp.39.8 billion, but unfortunately the realization is less effective. Therefore, to be a concern, especially for the Office of Cooperatives and SMEs in the Province of South Sumatra, to increase the role in recommending potential KUMKM in the target areas. LPDB-KUMKM partner candidates in accessing loans or financing LPDB-KUMKM are given easy access because they have entered into a cooperation agreement (PKS) with the Provincial Cooperative and SME Office of South Sumatra and a guarantee company, Jamkrindo and Jamkrida Sumsel. In addition, potential partners can also directly apply for loans to LPDB-KUMKM or by mail.

Entering an online business, slowly SMEs in South Sumatra are being addressed, by improving product quality and standardizing their products. Besides helping increase human resources and access to financing sources, collaboration between government and e-commerce will continue and be able to realize a shared vision to make MSMEs in South Sumatra able to participate in the era of Digital Energy of Asia in 2020. (Head of South Sumatra Cooperative and SME Service, 2018).

In an effort to encourage this growth, the provincial government of South Sumatra has facilitated new business actors and existing SMEs to expand their business by holding socialization and training in various district / city areas. Business actors can also get training, which cooperates with the Cooperative Education and Training Agency (UPTD Balatkop) in regencies / cities in South Sumatra. The trainings are funded with deconcentration funds. The funds amounting to 100 billion are allocated to 34 provinces in Indonesia. "So each province can get around 3 billion.

The Secretary of the Head of the Cooperative and Small and Medium Enterprises Office (Kemenkop and UKM, 2008) of South Sumatra Province said, it would provide facilities related to the problems faced by MSMEs. The Ministry of Cooperatives and SMEs will support and will provide training, capital by providing cooperative loan facilities for SMEs through the Revolving Fund Management Agency (LPDB). Through LPDB, facilitated SMEs for cooperatives can be capital loans with 7 percent interest. For business actors already legal entities can borrow 4.5 percent. In addition, Kemenkop and SMEs also encourage SMEs to be able to market products by utilizing e-commerce. Because now the world is entering the digital era. "Marketing, if you don't have a transformation tool room, is now the digital era, you can do business through online," which is in line with the development of the all-digital industry 4.0. Therefore, businesses must be prepared to enter this digital era, one of which is to market their products.

\section{Conclusion}

Various issues related to the distribution of revolving funds for Small and Medium Enterprises and Cooperatives in South Sumatra. The analysis was carried out by describing the absorption of revolving funds in MSMEs and the potential absorption of labor in the MSME sector quantitatively. The results of the analysis show that MSMEs in South Sumatra 
generally face some fundamental problems, pillars are self-sufficient. First, the problem of capital, both marketing, "For capital issues may still be overcome. Because the government through the banking and the Ministry of Cooperatives can provide sufficient access to provide loan capital. However, on the marketing side is still very lack of knowledge." Marketing is a problem. To overcome these problems, SMEs in South Sumatra were addressed, by improving product quality and standardizing their products. Besides helping increase human resources and access to financing sources, collaboration between government and e-commerce will continue and be able to realize a shared vision to make MSMEs in South Sumatra able to participate in the era of Digital Energy of Asia in 2020.

In an effort to encourage this growth, the provincial government of South Sumatra has facilitated new business actors and existing SMEs to expand their business by holding socialization and training in various district / city areas. Business actors can also get training, which cooperates with the Cooperative Education and Training Agency (UPTD Balatkop) in regencies / cities in South Sumatra. The trainings are funded with deconcentration funds

\section{References}

Mochtar, F. (2018). BI sebut tahun politik beri dampak positif bagi investasi RI. Source: https://www.merdeka.com/uang/bi-sebut-tahun-politik-beri-dampak-positif-bagi-investasi-ri. html

Kemenkop. (2008). UMKM. [Online] Available:

https://www.bi.go.id/id/tentang-bi/.../UU20Tahun2008UMKM.pdf

\section{Copyright Disclaimer}

Copyright for this article is retained by the author(s), with first publication rights granted to the journal.

This is an open-access article distributed under the terms and conditions of the Creative Commons Attribution license (http://creativecommons.org/licenses/by/3.0/). 